\title{
PENGARUH PENDAPATAN ASLI DAERAH, DANA PERIMBANGAN, DANA OTONOMI KHUSUS DAN TINGKAT KEMISKINAN TERHADAP TINGKAT KEMANDIRIAN KEUANGAN DAERAH DI KABUPATEN/KOTA PROVINSI ACEH
}

\author{
Machfud $^{1}$, Asnawi $^{2 *}$, Naz'aina $^{3}$ \\ ${ }^{1}$ Mahasiswa Pascasarjana Ilmu Manajemen, Fakultas Ekonomi dan Bisnis, Universitas Malikussaleh, \\ ${ }^{23}$ Dosen Pascasarjana Ilmu Manajemen, Fakultas Ekonomi dan Bisnis, Universitas Malikussaleh, \\ Email:machfud@gmail.com ${ }^{1}$,asnawi@unimal.ac.id ${ }^{2}$,nazaina@unimal.ac.id ${ }^{3}$
}

\section{ABSTRACT}

\begin{abstract}
This study aims to examine the effect of Regional Original Revenue, Balancing Funds, Special Autonomy Funds, and poverty levels on the level of local financial independence. The research data used is a combination of cross section with time series in 23 regencies / cities in Aceh Province during 2013-2018, obtained from the Budget Realization Report (LRA) issued by the Directorate General of Fiscal Balance of the Ministry of Finance (DJPK Ministry of Finance). The data analysis method used is Panel Data Regression with the help of Eviews 9. The results of this study prove that the Regional Original Revenue has a positive and significant effect on the level of regional financial independence, while the balance funds and special autonomy funds have a negative and significant effect on the level of regional financial independence. The poverty does not significantly influence the level of regional financial independence.
\end{abstract}

Keywords : Regional Original Revenue, Balancing Fund, Special Autonomy Funds, Poverty Levels and Financial Independency Ratio

\section{PENDAHULUAN}

Desentralisasi kewenangan pemerintah pusat ke pemerintah daerah memberikan proses pemberdayaan dan kemampuan suatu daerah dalam pengelolaan keuangan daerah. Menurut Halim (2007), tujuan kebijakan desentralisasi adalah untuk mewujudkan keadilan antara kemampuan dan hak daerah, peningkatan PAD dan pengurangan subsidi dari pemerintah pusat, serta mendorong pembangunan daerah sesuai dengan aspirasi masing-masing daerah. Selain itu, peranan pemerintah sendiri di antaranya menyusun usulan program kegiatan serta anggaran berdasarkan prinsip-prinsip anggaran kinerja dan dituangkan dalam rencana anggaran satuan kerja dengan mempertimbangkan kondisi ekonomi dan keuangan daerah (Haviz, 2016).

Pelaksanaan desentralisasi fiskal di Indonesia mengacu pada Undang-Undang Nomor 22 Tahun 1999 tentang Pemerintahan Daerah yang telah direvisi menjadi Undang-Undang Nomor 32 Tahun 2004, serta Undang-Undang Nomor 25 Tahun 1999 tentang Perimbangan Keuangan antara Pusat dan Daerah yang direvisi menjadi Undang-Undang Nomor 33 Tahun 2004. Kedua undangundang di bidang otonomi daerah tersebut telah menetapkan pemberian kewenangan otonomi dalam wujud otonomi yang luas, nyata, dan bertanggung jawab kepada daerah, pemerintah daerah diberi wewenang untuk menggali potensi daerahnya dan menetapkan prioritas pembangunan. Dengan pemberian otonomi daerah kabupaten dan kota, pengelolaan keuangan sepenuhnya berada ditangan pemerintah daerah. Pelaksanaan desentralisasi fiskal juga menjadi penting dalam meningkatkan pelayanan dan kesejahteraan rakyat daerah (Mardiasmo, 2011). Oleh karena itu, diperlukan sistem pengelolaan keuangan daerah yang baik dalam rangka mengelola dana desentralisasi secara transparan, ekonomis, efisien, efektif, dan akuntabel (Daod et al., 2013). Diberlakukannya undangundang ini memberikan peluang bagi daerah untuk menggali potensi lokal dan meningkatkan kinerja keuangannya dalam rangka mewujudkan kemandirian keuangan daerah.

Di Provinsi Aceh, beberapa peraturan daerah yang mengatur desentralisasi keuangan diantaranya Qanun Nomor 2 Tahun 2008 tentang tata cara pengalokasian tambahan dana bagi hasil dan gas bumi dan penggunaan dana otsus. Menurut Qanun tersebut, pembagian dana OTSUS untuk 
Kabupaten/Kota menggunakan mekanisme, dimana pengalokasian dana otsus tidak diberikan dalam bentuk uang tunai atau tidak ditransfer kepada kabupaten/kota. Mekanisme ini diubah dalam Qanun Nomor 2 Tahun 2013, dimana dana OTSUS langsung ditransfer oleh provinsi kepada kabupaten/kota dengan pembagian 40 persen dikelola oleh provinsi dan 60 persen dikelola oleh kabupaten/kota. Sementara itu, Berdasarkan UU No. 11 tahun 2006 tentang Pemerintahan Aceh, Pemerintah Aceh mendapatkan tambahan dana bagi hasil gas dan minyak bumi sebesar 55\% (lima puluh lima persen) untuk minyak dan $40 \%$ (empat puluh persen) untuk pertambangan gas bumi.

Adanya kekhawatiran yang muncul dari desentralisasi fiskal Aceh ialah, ketergantungan yang tinggi terhadap dana perimbangan dan memunculkan ketidakefienan belanja daerah. Ketidakefisienan yang dimaksud adalah rasio kontribusi dana perimbangan daerah yang lebih besar dari pada Pendapatan Asli Daerah (PAD) dalam membiayai belanja daerah, sehingga mengindikasikan bahwa daerah tersebut tidak mandiri dalam mengelola keuangannya. Kondisi ini dapat memunculkan stigma negatif kelemahan daerah dalam mengembangkan sumber penerimaan daerah yang berasal dari PAD. Selain itu, hal ini juga berkaitan dengan tingkat kemiskinan, dimana Aceh merupakan daerah termiskin di Sumatera dan ke enam secara nasional per September 2019 dengan tingkat kemiskinan mencapai $15,01 \%$. Hal ini cukup dibilang mengkhawatirkan, dimana Aceh dengan dana yang begitu berlimpah dari pusat tetapi tetap belum mampu memberikan keejahteraan kepada masyarakatnya dan memberikan indikasi bahwa Aceh secara keuangan belum mandiri. Maka dari itu, kemandirian daerah menjadi aspek penting untuk diperhatikan di Provinsi Aceh agar pengelolaan desentralisasi fiskal di Aceh dapat efektif dan efisien.

.Riset-riset sebelumnya membuktikan bahwa tingkat kemandirian daerah di Provinsi Aceh cenderung menurun. Hasil penelitian selama periode 2011-2013 menemukan bahwa kemandirian daerah Kabupaten/Kota di Provinsi Aceh memiliki rata-rata sebesar 8,21\% (Indriati, 2015), kemudian menurun menjadi 7,53\% untuk periode 2013-2015 (Khairul \& Isnaini, 2016).

Beberapa studi sebelumnya telah mendokumentasikan bahwa beberapa faktor yang mempengaruhi rasio kemandirian keuangan daerah di antaranya pendapatan asli daerah, dana perimbangan, dana otonomi khusus serta tingkat kemiskinan (Purnama, 2016; Anjani, 2016; Budianto \& Alexander, 2016; Tamberan \& Djanggo, 2019; Heryanti et al., 2019; Sholihin, 2012; Ilyas \& Syafri, 2016). Akan tetapi, masih terdapat beberapa studi yang mendokumentasikan hasil yang berbeda, dimana pendapatan asli daerah, dana perimbangan dan dana otonomi khusus tidak berpengaruh signifikan terhadap rasio kemandirian keuangan daerah (Nufus \& Asmara, 2017; Andriani \& Wahid, 2019; Nurhasanah \& Maria, 2018; Erawati \& Suzan, 2015; Indrawan, 2016; Setyawati, 2018; Aulia, 2018). Ini menunjukkan bahwa masih terjadi perdepatan di antara para peneliti mengenai pengaruh pendapatan asli daerah, dana perimbangan dan dana otonomi khusus terhadap rasio kemandirian daerah, sehingga memotivasi penulis untuk mengkajinya kembali di Provinsi Aceh.

\section{Literature Review dan Hipotesis}

\section{Pengaruh PAD terhadap Tingkat Kemandirian Keuangan Daerah}

PAD yang tinggi akan menunjukkan kemampuan daerah dalam memenuhi kebutuhannya sendiri dan memelihara serta mendukung hasil-hasil pembangunan yang telah dilaksanakan dan yang akan dilaksanakan (Dewi \& Saputra, 2017). Selanjutnya, kemandirian keuangan daerah dapat dilihat dari besarnya pendapatan asli daerah yang diperoleh oleh tiap pemerintahan kabupaten/kota. Semakin besar pendapatan asli daerah dibandingkan dengan bantuan yang diberikan pemerintah pusat, maka pemerintah kota tersebut tingkat kemndirian keuangan daerahnya tinggi (Andriani \& Wahid, 2018). Pendapatan asli daerah yang merupakan sumber pembiayaan yang memang benar-benar digali dari daerah itu sendiri sehingga dapat mencerminkan kondisi riil daerah dan menunjukkan kemandirian keuangan daerah (Nufus \& Asmara, 2017). Jika nantinya struktur pendapatan asli daerah kuat boleh dikatakan daerah tersebut memiliki kemampuan pembiayaan yang kuat (Nurhasanah \& Maria, 2018). Uraian tersebut menunjukkan bahwa PAD berpengaruh positif dan signifikan terhadap rasio keamndirian keuangan daerah.

Pengaruh PAD terhadap rasio kemandirian keuangan daerah juga telah dibuktikan oleh beberapa riset sebelumnya. Seperti hasil penelitian Hernayanti et al. (2019) di Kabupaten/Kota pada Provinsi Jawa Timur yang membuktikan bahwa PAD memberikan pengaruh positif dan signifikan terhadap rasio kemandirian keuangan daerah. Hal tersebut juga didukung oleh temuan Purnama (2016) yang membuktikan bahwa PAD berpemgaruh positif dan signifikan terhadap rasio 
kemandirian keuangan daerah pada Kabupaten/Kota di Provinsi Lampung. Sementara itu, hasil penelitian Anjani et al. (2016) di Provinsi NTB menemukan bahwa peningkatan PAD akan mendorong kemandirian keuangan daerah juga meningkat.

\section{Pengaruh Dana Perimbangan terhadap Tingkat Kemandirian Keuangan Daerah}

Dana perimbangan merupakan salah satu sumber penerimaan daerah yang memiliki kontribusi besar terhadap struktur APBD (Halim, 2007). Dalam UU No. 33 Tahun 2004, disebutkan bahwa dana perimbanagan adalah dana yang bersumber dari APBN yang dialokasikan kepada daerah untuk mendanai kebutuhan daerah dalam rangka pelaksanaan desentralisasi. Perimbangan keuangan antara pemerintah pusat dan pemerintah daerah adalah suatu sistem pembagian keuangan yang adil, proporsional, demokratis, transparan dan efisien dalam rangka pendanaan penyelenggaraan desentralisasi dengan mempertimbangkan potensi, kondisi, dan kebutuhan daerah, serta besaran pendanaan dekonsentrasi dan tugas pembantuan (Andriani \& Wahid, 2018). Akan tetapi, diharapkan setiap daerah tidak menjadikan dana perimbangan sebagai sumber utama pendapatan daerah tapi menjadikannya sebagai sumber pendapatan pendukung bagi pelaksanaan pemerintahan dan pembangunan daerah (Budianto \& Alexander, 2016), sehingga tingkat ketergantungan daerah terhadap pemerintah pusat dalam pembiayaan daerahnya semakin kecil (Kustianingsih et al., 2018). Semakin kecilnya tingkat ketergantungan tersebut, maka suatu daerah dapat dikatakan mandiri (Sanga et al., 2018). Uraian tersebut menunjukkan bahwa dana perimbangan berpengaruh negatif terhadap rasio kemandirian keuangan daerah.

Pengaruh dana perimbangan terhadap rasio kemandirian keuangan daerah telah dijelaskan oleh beberapa studi sebelumnya. Seperti penelitian yang dilakukan oleh Heryanti et al. (2019) di Kabupaten/Kota yang ada di Provinsi Jawa Timur yang membuktikan bahwa dana perimbangan berpengaruh negatif dan signifikan terhadap rasio kemandirian keuangan daerah. Sejalan dengan temuan Purnama (2016) yang membuktikan bahwa dana perimbangan berpengaruh negatif dan signifikan terhadap rasio kemandirian keuangan daerah pada Kabupaten/Kota di Provinsi Lampung. Selanjutnya, Budianto \& Alexander (2016) juga memberikan bukti empiris bahwa semakin rendah dana perimbangan, maka rasio kemandirian keuangan daerah akan semakin tinggi.

Pengaruh Dana Otonomi Khusus terhadap Tingkat Kemandirian Keuangan Daerah

Dana Otonomi Khusus merupakan dana yang didapatkan oleh Provinsi Aceh melalui UndangUndang Nomor 11 Tahun 2006 Tentang Pemerintahan Aceh. Dana Otonomi Khusus diperuntukkan untuk mempercepat pembangungan Provinsi Aceh yang ditujukan untuk membiayai pembangunan terutama pembangunan dan pemeliharaan infra struktur, pemberdayaan ekonomi rakyat, pengentasan kemiskinan, serta pendanaan pendidikan, sosial, dan kesehatan. Pemanfaatan Dana Otonomi Khusus dalam rangka mempercepat pembangunan di Aceh dalam berbagai sektor akan terwujud apabila pelaksanaannya sesuai dengan asas-asas yang termuat dalam Pasal 20 Undang-Undang Nomor 11 Tahun 2006 Tentang Pemerintahan Aceh, yaitu dengan berorientasi pada tujuan yang tepat guna dan berdaya guna. Hal ini menunjukkan bahwa penggunaan dana otonomi khusus yang optimal akan mendorong tingkat kemandirian keuangan daerah.

OTSUS merupakan dana yang diberikan oleh pemerintah pusat kepada Aceh. Ketergantungan Aceh terhadap dana OTSUS tentunya memberikan indikasi bahwa Aceh belum memiliki kemandirian keuangan yang baik. Beberapa penelitian mengenai pengaruh dana otonomi khusus terhadap rasio keuangan kemandirian telah membuktikan bahwa dana otonomi khusus berpengaruh negatif dan signifikan terhadap rasio kemandirian keuangan suatu daerah. Nufus \& Asmara (2017) menemukan bahwa dana OTSUS memberikan pengaruh negatif dan signifikan terhadap rasio kemandirian keuangan daerah pada Provinsi Aceh. Selenjutnya, Tamberan \& Djanggo (2019) membuktikan secara empiris bahwa semakin tinggi otonomi khusus, maka kemandirian daerah akan semakin menurun.

\section{Pengaruh Tingkat Kemiskinan terhadap Tingkat Kemandirian Keuangan Daerah}

Kemiskinan merupakan suatu keadaan dimana seseorang tidak mampu memenuhi kebutuhan pokoknya. Kemiskinan sering sekali diidentifikasikan dnegan keadaan daerah yang masih belum mandiri secara keuangannyaa, karena tidak mampu meningkatkan kesejahteraan dan pendapatan masyarakat daerah (Febriandari \& Suseno, 2016). Ketika suatu daerah tergolong memiliki tingkat kemiskinan yang tinggi, maka daerah tersebut juga memiliki tingkat kemandirian yang rendah. Hal ini dikarenakan ketika kemiskinan meningkat, penggunaan dana dari pusat juga meningkat (Asmara \& Suci, 2014). Dengan kata lain, kemiskinan berpengaruh negatif dan signifikan terhadap tingkat 
kemandirian keuangan daerah. Beberapa studi sebelumnya juga telah membuktikan bahwa kemiskinan berpengaruh negatif dan signifikan terhadap rasi kemandirian keuangan daerah (Sholihin, 2012; Ilyas \& Syafri, 2016).

Berdasarkan uraian di atas, maka hipotesis yang dapat dibangun dalam penelitian ini adalah sebagai berikut:

$\mathrm{H}_{1} \quad$ : Pendapatan Asli Daerah (PAD) berpengaruh positif dan signifikan terhadap tingkat kemandirian keuangan daerah Kabupaten/Kota di Provinsi Aceh.

$\mathrm{H}_{2}$ : Dana Perimbangan (DP) berpengaruh negatif dan signifikan terhadap tingkat kemandirian keuangan daerah Kabupaten/Kota di Provinsi Aceh.

$\mathrm{H}_{3} \quad$ : Dana Otonomi Khusus (OTSUS) berpengaruh negatif dan signifikan terhadap tingkat kemandirian keuangan daerah Kabupaten/Kota di Provinsi Aceh.

$\mathrm{H}_{4} \quad$ : Tingkat kemiskinan berpengaruh negatif dan signifikan terhadap tingkat kemandirian keuangan METODE daerah Kabupaten/Kota di Provinsi Aceh.

Objek dalam penelitian ini adalah PAD, dana perimbangan, OTSUS dan tingkat kemiskinan di Kabupaten/Kota di Provinsi Aceh selama periode 2013-2018 yaitu sebanyak 23 Kabupaten/Kota. Penelitian ini dilakukan dengan mengakses situs resmi Direktorat Jendral Perimbangan Keuangan (DJPK) yang diakses memalui situs resemi yaitu www.djpk.kemenkeu.go.id.

Jenis data yang digunakan dalam penelitian ini adalah data panel. Sugiyono (2016) mengatakan bahwa data Panel (pooled data) adalah data gabungan antara time series data dengan cross section data. Dikatakan data gabungan karena data ini terdiri atas beberapa objek dalam beberapa periode waktu. Periode dalam penelitian ini selama selama 2013-2018 (time series) dan objek sebanyak 23 Kabupaten/Kota (Cross Section) sehingga banyaknya observasi dalam penelitian ini adalah 184 observasi.

Penelitian ini secara umum menggunakan 1 variabel terikat dan 4 variabel bebas. Variabel terikat dalam penelitian ini adalah tingkat kemandirian daerah yang diukur dengan jumlah PAD dibagi jumlah pendapatan (Syamsudin et al., 2015; Berliani, 2016; Harahap et al., 2018). Sementara itu, variabel bebas dalam penelitian ini terdiri dari PAD yang diukur dalam satuan Rupiah, DP diukur dengan satuan Rupiah, OTSUS diukur dengan satuan Rupiah dan tingkat kemiskinan diukur dalam satuan persentase..

Adapun persamaan statistik yang akan diuji dalam penelitian ini adalah sebagai berikut:

$\mathrm{RKKD}_{\mathrm{it}}=\beta_{0}+\beta 1 \mathrm{LnPAD}_{\mathrm{it}}+\beta_{2} \mathrm{LnDP}_{\mathrm{it}}+\beta_{3}$ LnOTSUS $_{\mathrm{it}}+\beta_{4}$ Kemiskinan $_{\mathrm{it}}+\varepsilon_{\mathrm{it}}$

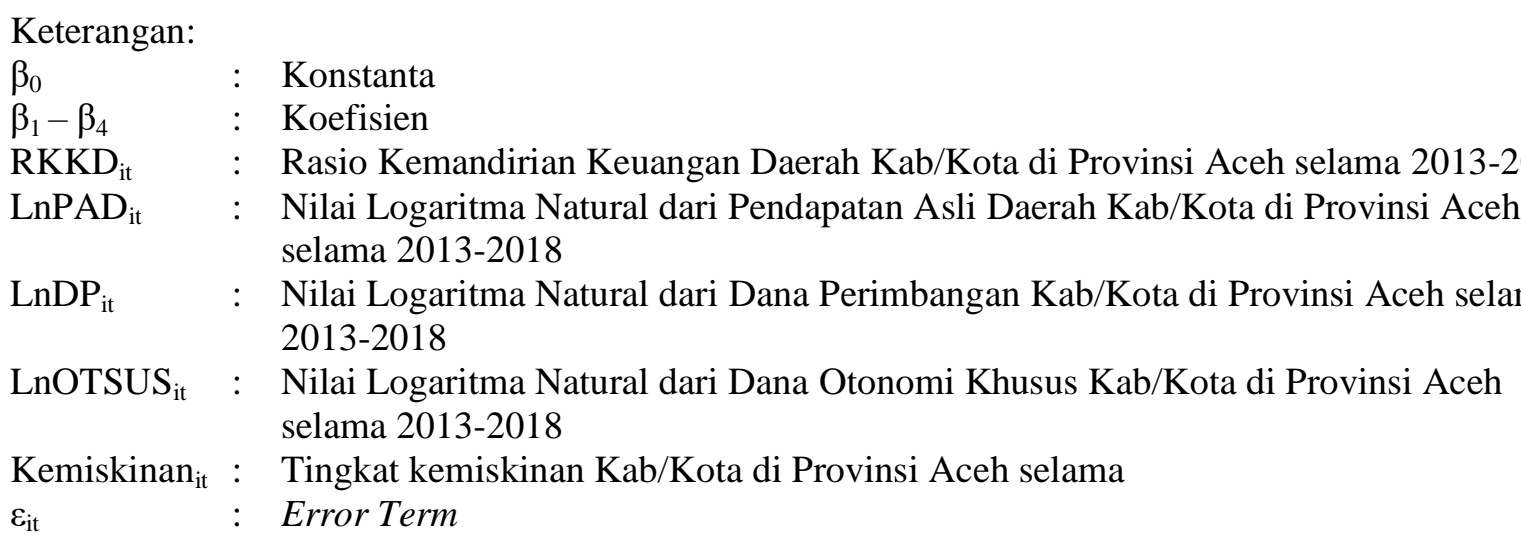

\section{HASIL PENELITIAN DAN PEMBAHASAN}

\section{Analisis Deskriptif Statistik}

Pada analisis statistik deskriptif, akan terlihat bagaimana nilai rata-rata, nilai standar deviasi, nilai maksimum dan nilai minimum dari data yang digunakan dalam penelitian ini. Adapun hasil analisis deskriptif dalam penelitian ini adalah sebagai berikut:

\section{Tabel 1}


Analisis Deskriptif Statistik

\begin{tabular}{lrrrrr}
\hline \multicolumn{1}{c}{ Mean } & \multicolumn{1}{c}{ Std Dev } & \multicolumn{1}{c}{ Max } & \multicolumn{1}{c}{ Min } & \multicolumn{1}{c}{ Obs } \\
\hline RKKD & 0.1098 & 0.0912 & 0.8576 & 0.0260 & 138 \\
PAD (Rp Juta) & 94,100 & 68,100 & 388,000 & 8,290 & 138 \\
DP (Rp Juta) & 707,000 & 228,000 & $1,340,000$ & 305,000 & 138 \\
OTSUS (Rp Juta) & 153,000 & 136,000 & 643,000 & 9,120 & 138 \\
Kemiskinan & 0.1724 & 0.0380 & 0.2370 & 0.0725 & 138 \\
\hline 2020 & \multicolumn{7}{c}{} \\
OTSUS dalam satuan juta Rupiah, sedangkan Kemiskinan dan RKKD dalam angka desimal
\end{tabular}

Berdasarkan Tabel 1 di atas, terlihat bahwa rasio kemandirian keuangan daerah (RKKD) memiliki nilai rata-rata sebesar 0.1098 dengan standar deviasinya sebesar 0.0912. Nilai rata-rata lebih tinggi dibandingkan dengan standar deviasinya yang menunjukkan bahwa fluktuasi data RKKD dalam penelitian ini memiliki fluktuasi yang kecil. Nilai tertinggi RKKD dalam penelitian ini sebesar 0.8576 dan nilai terendahnya sebesar 0.0260 dengan jumlah observasi sebanyak 138 observasi.

Selanjutnya, nilai rata-rata PAD dalam penelitian ini sebesar Rp 94,100,000,000 dengan standar deviasinya sebesar Rp 68,100,000,000. Hasil ini menunjukkan bahwa rata-rata PAD lebih besar dibandingkan dengan standar deviasinya, sehingga dapat disimpulkan bahwa fluktuasi data PAD dalam penelitian ini tergolong kecil. Nilai tertinggi PAD sebesar Rp 388,000,000,000 dan nilai terendahnya sebesar Rp 8,290,000,000 untuk 138 observasi.

Selanjutnya, Dana Perimbangan (DP) memiliki nilai rata-rata sebesar Rp 707,000,000,000 dengan standar deviasinya sebesar Rp 228,000,000,000. Hasil tersebut menunjukkan bahwa rata-rata dana perimbangan lebih besar dibandingkan dengan standar deviasinya, sehingga dapat dikatakan bahwa fluktuasi dana perimbangan dalam penelitian ini tergolong kecil. Nilai tertinggi dana

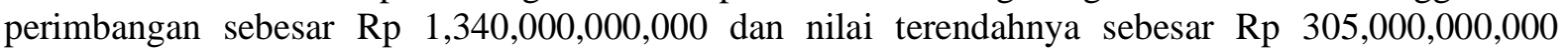
dengan jumlah observasi sebanyak 138 observasi.

Selanjutnya, OTSUS memiliki nilai rata-rata sebesar Rp 153,000,000,000 dengan nilai standar deviasinya sebesar Rp 136,000,000,000. Hasil ini menunjukkan bahwa OTSUS memiliki nilai ratarata yang lebih besar dibandingkan dengan nilai standar deviasinya, sehingga fluktuasi data OTSUS dalam penelitian ini tergolong kecil. Nilai tertinggi OTSUS sebesar Rp 643,000,000,000 dan nilai terendahnya sebesar Rp 9,120,000,000 untuk 138 observasi.

Kemiskinan dalam penelitian ini memiliki nilai rata-rata sebesar 0.1724 dengan standar deviasinya sebesar 0.0380 . Nilai rata-rata lebih besar dibandingkan dengan standar deviasnya yang menunjukkan bahwa fluktuasi data kemiskinan dalam penelitian ini tergolong dalam fluktuasi yang kecil. Nilai tertinggi kemiskinan sebesar 0.2370 dan nilai terendahnya sebesar 0.0725 dengan jumlah observasi sebanyak 138 observasi.

\section{Analisis Korelasi}

Analisis korelasi merupakan tahapan pengujian untuk melihat hubungan (korelasi) dari setiap variabel yang digunakan dalam penelitian ini. Adapun hasil analisis korelasi dalam penelitian ini dapat dilihat sebagai berikut:

Tabel 2

\section{Analisis Korelasi}

\begin{tabular}{|c|c|c|c|c|c|}
\hline & RKKD & LN_PAD & LN_DP & LN_OTSUS & KEMISKINAN \\
\hline \multirow{2}{*}{ RKKD } & 1.0000 & & & & \\
\hline & ---- & & & & \\
\hline \multirow{2}{*}{ LN_PAD } & 0.5133 & 1.0000 & & & \\
\hline & $(6.9751)^{* * *}$ & ----- & & & \\
\hline \multirow{2}{*}{ LN_DP } & 0.2100 & 0.7844 & 1.0000 & & \\
\hline & $(2.5051)^{* * *}$ & $(14.7510)^{* * *}$ & ----- & & \\
\hline \multirow{2}{*}{ LN_OTSUS } & 0.1349 & 0.6525 & 0.7294 & 1.0000 & \\
\hline & (1.5885) & $(10.0439)^{* * *}$ & $(12.4376)^{* * *}$ & ----- & \\
\hline \multirow{2}{*}{ KEMISKINAN } & -0.3165 & -0.3570 & -0.1619 & -0.0590 & 1.0000 \\
\hline & $(-3.8910)^{* * *}$ & $(-4.4582) * * *$ & $(-1.9143)^{*}$ & $(-0.6895)$ & ----- \\
\hline
\end{tabular}

$\begin{array}{ll}\text { Sumber : } & \text { Data Diolah, } 2020 \\ \text { Keterangan : } & * * *, * *, * \text { signifikan pada level } 1 \%, 5 \% \text { dan } 10 \%\end{array}$


Berdasarkan Tabel 2 di atas, terlihat bahwa PAD dan DP berkorelasi positif dengan RKKD masing-masing sebesar 0.5133 dan 0.2100 dan signifikan pada level $1 \%$ dan $5 \%$, sedangkan kemiskinan berkorelasi negatif dengan RKDD sebesar -0.3165 dan signifikan di level $1 \%$. Adapun OTSUS berkorelasi positif dengan RKDD sebesar 0.1349 tetapi tidak signifikan secara statistik. Untuk hubungan antar variabel bebas, ditemukan bahwa DP dan OTSUS berkorelasi positif dengan PAD masing-masing sebesar 0.7844 dan 0.6525 dan signifikan di level 1\%, sedangkan kemiskinan berkorelasi negatif dengan PAD dengan besaran korelasi yaitu -0.3570 dan signifikan di level $1 \%$. Selanjutnya, OTSUS berkorelasi dengan DP sebesar 0.7294 dan signifikan di level $1 \%$, dan kemiskinan berkorelasi negatif dengan DP sebesar -0.1619 dan signifikan di level $10 \%$. Adapun kemiskinan berkorelasi negatif dengan OTSUS sebesar -0.0590 tetapi tidak signifikan.

\section{Teknik Pemilihan Model}

Agar model yang digunakan baik dan sesuai, maka diperlukan penaksiran model. Terdapat tiga model di dalam regresi data panel yaitu Common Effect Model (CEM) atau Pooled Least Square, Fixed Effect Model (FEM) dan Random Effect Model (REM). Untuk menentukan model terbaik dan yang sesuai dengan penelitian ini, maka uji yang dilakukan yaitu Uji Chow dan Uji Hausman. Uji Chow dilakukan untuk membandingkan model CEM dan FEM sedangkan Uji Hausman dilakukan untuk membandingkan FEM dan REM.

\section{Tabel 3}

Uji Chow

\begin{tabular}{lrrl}
\hline \multicolumn{1}{c}{ Effects Test } & \multicolumn{1}{c}{ Statistic } & \multicolumn{1}{c}{ d.f. } & \multicolumn{1}{l}{ Prob. } \\
\hline Cross-section F & 1.1668 & $(22,111)$ & 0.2922 \\
Cross-section Chi-square & 28.7105 & 22 & 0.1533 \\
\hline
\end{tabular}

Sumber : Data Diolah, 2020

Berdasarkan Tabel 3 di atas, terlihat bahwa nilai Probability Chi Square sebesar 0.1533, dimana nilai tersebut berada di atas nilai toleransi kesalahan di dalam penelitian ini (0.05). Dengan kata lain, hasil Uji Chow memilih Common Effect Model (CEM) sebagai model terbaik, sehingga dilanjutkan dengan Uji LM untuk menguji model terbaik antara CEM dan REM.

Tabel 4

\section{Uji LM}

\begin{tabular}{lcc}
\hline & Statistic & Prob. \\
\hline Bruech Pagan Value & 0.0025 & 0.9595 \\
\hline
\end{tabular}

Sumber : Data Diolah, 2020

Berdasarkan Tabel 5.4 di atas, ditemukan nilai probability untuk Bruech Pagan Value sebesar 0.9595, dimana nilai tersebut berada di atas nilai toleransi kesalahan dalam penelitian ini (0.05). Hal ini menunjukkan bahwa model terbaik dalam penelitian ini adalah Common Effect Model (CEM), sehingga pengujian asumsi klasik, estimasi regresi dan pengujian hipotesis penelitian dilakukan dengan regresi Common Effect Model (CEM).

\section{Estimasi Regresi Linear Berganda}

Hasil pemilihan model menunjukkan bahwa model yang tepat untuk diestimasikan dalam penelitian ini adalah Common Effect Model. Adapun hasil regresi secara Common Effect Model (CEM) dapat dilihat pada Tabel 5.6 di bawah ini:

1. Estimasi Common Effect Model untuk Overall Model

Hasil regresi Common Effect Model untuk menguji pengaruh PAD, DP, OTSUS dan kemiskinan terhadap RKKD secara keseluruhan (overall model) disajikan pada Tabel 5.6 berikut: 


\section{Tabel 5}

Common Effect Model untuk Overall Model

\begin{tabular}{ccr}
\hline Variabel & Koefisien & \multicolumn{1}{c}{$\mathrm{t}_{\text {hitung }}$} \\
\hline C & 0.7663 & 1.0827 \\
LN_PAD & 0.1130 & $7.4162 * * *$ \\
LN_DP & -0.1105 & $-3.0110^{* * *}$ \\
LN_OTSUS & -0.0176 & $-1.8086 *$ \\
KEMISKINAN & -0.1549 & -0.8536 \\
\hline R-squared & & 0.3817 \\
Adjusted R-squared & & 0.3631 \\
F-statistic & & $20.5293 * * *$ \\
Durbin-Watson & & 1.2184
\end{tabular}

Sumber

$$
\text { : Data Diolah, } 2 \overline{020}
$$

Keterangan : $* * *, * * *$ signifikan pada level $1 \%, 5 \%$ dan $10 \%$

Berdasarkan Tabel 5 di atas, maka persamaan statistik yang dapat dibentuk dalam penelitian ini adalah sebagai berikut:

RKKD $=0.7663+0.1130$ LN_PAD -0.1105 LN_DP -0.0176 LN_OTSUS -0.1549 KEMISKINAN

Berdasarkan Persamaan di atas, terlihat bahwa nilai konstanta dalam penelitian ini sebesar 0.7663. Ini menunjukkan bahwa ketika PAD, Dana Perimbangan, OTSUS dan kemiskinan bernilai 0, maka kemandirian keuangan daerah akan tetap konstan sebesar 0.7663. Selanjutnya, PAD berpengaruh positif terhadap rasio keuangan kemandirian daerah dengan koefisien regresi sebesar 0.1130. Ini menunjukkan bahwa ketika PAD naik $1 \%$, maka rasio kemandirian daerah akan meningkat sebesar 0.1130. Nilai koefisien tersebut juga tergolong signifikan di level $1 \%$ dengan nilai $t_{\text {hitung }}$ sebesar 0.1130. Dengan kata lain, PAD berpengaruh positif dan signifikan terhadap rasio kemandirian keuangan daerah kabupaten/kota di Provinsi Aceh, sehingga $\mathrm{H}_{1}$ diterima.

Selanjutnya, dana perimbangan berpengaruh negatif dan signfiikan terhadap rasio kemandirian keuangan daerah dengan nilai koefisien regresi sebesar -0.1105. Nilai tersebut menunjukkan bahwa ketika dana perimbangan naik 1\%, maka rasio kemandirian keuangan daerah akan menurun sebesar 0.1105 . Nilai koefisien tersebut juga tergolong signifikan di level $1 \%$ dengan nilai $t_{\text {hitung }}$ sebesar -3.0110. Dengan kata lain, $\mathrm{H}_{2}$ diterima yang artinya dana perimbangan berpengaruh negatif dan signifikan terhadap rasio kemandirian keuangan daerah kabupaten/kota di Provinsi Aceh.

OTSUS berpengaruh negatif terhadap rasio kemandirian keuangan daerah dengan koefisien regresi sebesar -0.0176. Nilai tersebut menunjukkan bahwa ketika OTSUS naik 1\%, maka rasio kemandirian keuangan daerah akan menurun sebesar 0.0176. Nilai koefisien tersebut juga tergolong signifikan di level 10\% secara statistik dengan nilai $t_{\text {hitung }}$ sebesar -1.8086. Dengan kata lain, OTSUS berpengaruh negatif dan signifikan terhadap rasio kemandirian keuangan daerah Kabupaten/Kota di Provinsi Aceh, sehingga $\mathrm{H}_{3}$ diterima.

Adapun kemiskinan berpengaruh negatif dengan koefisien regresi sebesar -0.1549. Hal ini menunjukkan bahwa ketika kemiskinan meningkat 1\%, maka kemandirian keuangan daerah akan menurun sebesar 0.1549. Akan tetapi, nilai tersebut tidak tergolong signifikan secara statistik, sehingga $\mathrm{H}_{4}$ ditolak, yang artinya kemiskinan tidak berpengaruh signifikan terhadap rasio kemandirian keuangan daerah kabupaten/kota di Provinsi Aceh.

Berdasarkan Tabel 5di atas, terlihat bahwa nilai Adjusted R-Square sebesar 0.3631 (36.31\%). Hal ini menunjukkan bahwa PAD, DP, OTSUS dan kemiskinan mampu menjelaskan rasio kemandirian keuangan daerah sebesar $36.31 \%$, sedangkan sisanya $63.69 \%$ dijelaskan oleh faktorfaktor lain yang tidak dianalisis dalam penelitian ini. Selanjutnya, nilai F-Statistik dalam penelitian ini sebesar 20.5293, dimana nilai tersebut signifikan pada level $1 \%$. 
1. Estimasi Common Effect Model untuk Categorical Model

Hasil regresi Common Effect Model untuk menguji pengaruh PAD, DP, OTSUS dan Kemiskinan terhadap RKKD per wilayah (Kabupaten/Kota) di Provinsi Aceh disajikan pada Tabel 6 berikut:

\section{Tabel 6}

Common Effect Model untuk Model per Wilayah

\begin{tabular}{|c|c|c|}
\hline Variable & Coefficient & t-Statistic \\
\hline $\mathrm{C}$ & -0.5002 & -0.0390 \\
\hline $\mathrm{CODE}=2$ & -6.6261 & -0.4009 \\
\hline $\mathrm{CODE}=3$ & 0.4234 & 0.0281 \\
\hline $\mathrm{CODE}=4$ & 0.4342 & 0.0229 \\
\hline $\mathrm{CODE}=5$ & -15.3168 & -0.7799 \\
\hline $\mathrm{CODE}=6$ & -2.1438 & -0.1177 \\
\hline $\mathrm{CODE}=7$ & 0.3647 & 0.0108 \\
\hline $\mathrm{CODE}=8$ & -1.0746 & -0.0658 \\
\hline $\mathrm{CODE}=9$ & 51.8864 & 1.6718 \\
\hline $\mathrm{CODE}=10$ & -0.3189 & -0.0131 \\
\hline $\mathrm{CODE}=11$ & 1.6351 & 0.0718 \\
\hline $\mathrm{CODE}=12$ & 0.5091 & 0.0369 \\
\hline $\mathrm{CODE}=13$ & 1.4386 & 0.0835 \\
\hline $\mathrm{CODE}=14$ & 1.5696 & 0.0934 \\
\hline $\mathrm{CODE}=15$ & -2.7069 & -0.0871 \\
\hline $\mathrm{CODE}=16$ & -0.0615 & -0.0039 \\
\hline $\mathrm{CODE}=17$ & 0.4069 & 0.0259 \\
\hline $\mathrm{CODE}=18$ & 0.4471 & 0.0300 \\
\hline $\mathrm{CODE}=19$ & -6.9892 & -0.2469 \\
\hline $\mathrm{CODE}=20$ & 1.0490 & 0.0728 \\
\hline $\mathrm{CODE}=21$ & 23.8841 & 1.1342 \\
\hline $\mathrm{CODE}=22$ & 0.5656 & 0.0304 \\
\hline $\mathrm{CODE}=23$ & 2.3143 & 0.1658 \\
\hline LN_PAD*(CODE=1) & 0.0631 & 0.5965 \\
\hline LN_PAD*(CODE=2) & -0.2155 & $-1.8208^{*}$ \\
\hline LN_PAD*(CODE=3) & 0.0699 & 0.4579 \\
\hline LN_PAD*(CODE=4) & 0.0624 & 0.5886 \\
\hline LN_PAD*(CODE=5) & 0.0701 & 0.6352 \\
\hline LN_PAD*(CODE=6) & 0.1719 & 1.0547 \\
\hline LN_PAD*(CODE=7) & 0.0882 & 0.4288 \\
\hline LN_PAD*(CODE=8) & 0.1294 & 0.7131 \\
\hline LN_PAD*(CODE=9) & -0.4217 & $-2.4177 * *$ \\
\hline LN_PAD*(CODE $=10)$ & 0.1004 & 0.3387 \\
\hline LN_PAD $*(C O D E=11)$ & 0.1715 & $2.6002 * *$ \\
\hline LN_PAD*(CODE $=12)$ & 0.1151 & 0.4826 \\
\hline $\mathrm{LN} \_\mathrm{PAD} *(\mathrm{CODE}=13)$ & 0.0630 & 0.6780 \\
\hline
\end{tabular}




\begin{tabular}{|c|c|c|}
\hline LN_PAD*(CODE $=14)$ & 0.0746 & 0.2792 \\
\hline LN_PAD $*(C O D E=15)$ & 0.0731 & 0.9216 \\
\hline LN_PAD*(CODE=16) & 0.0666 & 0.2913 \\
\hline LN_PAD*(CODE=17) & 0.0677 & 0.6457 \\
\hline LN_PAD*(CODE=18) & 0.0477 & 0.2005 \\
\hline LN_PAD*(CODE=19) & 0.4286 & $1.7940 *$ \\
\hline LN_PAD*(CODE=20) & 0.1142 & 0.5743 \\
\hline LN_PAD*(CODE=21) & 0.3111 & 1.0854 \\
\hline LN_PAD*(CODE=22) & 0.0750 & 0.1461 \\
\hline LN_DP*(CODE=1) & -0.0330 & -0.0665 \\
\hline LN_DP*(CODE=2) & 0.4448 & 0.9581 \\
\hline LN_DP*(CODE=3) & -0.0464 & -0.1110 \\
\hline $\mathrm{LN} \_\mathrm{DP} *(\mathrm{CODE}=4)$ & -0.0387 & -0.0652 \\
\hline LN_DP*(CODE $=5)$ & 0.4581 & 0.8354 \\
\hline LN_DP*(CODE $=6)$ & -0.0180 & -0.0323 \\
\hline LN_DP*(CODE=7) & -0.1547 & -0.1331 \\
\hline $\mathrm{LN} \_\mathrm{DP} *(\mathrm{CODE}=8)$ & -0.0455 & -0.1102 \\
\hline LN_DP*(CODE=9) & -1.7763 & -1.5040 \\
\hline LN_DP*(CODE=10) & -0.0264 & -0.0243 \\
\hline LN_DP*(CODE=11) & -0.1776 & -0.2549 \\
\hline LN_DP*(CODE=12) & -0.0912 & -0.3809 \\
\hline LN_DP*(CODE=13) & -0.0862 & -0.1961 \\
\hline LN_DP*(CODE=14) & -0.0827 & -0.3171 \\
\hline LN_DP*(CODE=15) & 0.0595 & 0.0729 \\
\hline LN_DP*(CODE=16) & -0.0368 & -0.1249 \\
\hline LN_DP*(CODE=17) & -0.0646 & -0.1725 \\
\hline LN_DP*(CODE=18) & -0.0300 & -0.0961 \\
\hline LN_DP*(CODE=19) & -0.1315 & -0.1485 \\
\hline LN_DP*(CODE=20) & -0.1152 & -0.4071 \\
\hline LN_DP*(CODE=21) & -0.1423 & -0.2452 \\
\hline LN_DP*(CODE=22) & -0.0569 & -0.1457 \\
\hline LN_DP*(CODE=23) & -0.0734 & -0.3837 \\
\hline LN_OTSUS $*(C O D E=1)$ & -0.0113 & -0.1281 \\
\hline LN_OTSUS $*(C O D E=2)$ & 0.0395 & 0.6812 \\
\hline LN_OTSUS $*(\mathrm{CODE}=3)$ & -0.0107 & -0.0739 \\
\hline LN_OTSUS $*(\mathrm{CODE}=4)$ & -0.0131 & -0.0901 \\
\hline LN_OTSUS*(CODE=5) & -0.0055 & -0.0795 \\
\hline LN_OTSUS $*(\mathrm{CODE}=6)$ & -0.0524 & -0.3257 \\
\hline LN_OTSUS*(CODE=7) & 0.0627 & 0.1825 \\
\hline LN_OTSUS $*(\mathrm{CODE}=8)$ & -0.0237 & -0.2354 \\
\hline LN_OTSUS $*(\mathrm{CODE}=9)$ & 0.7951 & $2.7429 * *$ \\
\hline LN_OTSUS $*(\mathrm{CODE}=10)$ & -0.0343 & -0.2606 \\
\hline LN_OTSUS $*(\mathrm{CODE}=11)$ & -0.0336 & -0.8242 \\
\hline LN_OTSUS $*(C O D E=12)$ & -0.0219 & -0.1244 \\
\hline
\end{tabular}




\begin{tabular}{|c|c|c|}
\hline LN_OTSUS $*(C O D E=13)$ & -0.0024 & -0.0445 \\
\hline LN_OTSUS*(CODE=14) & -0.0121 & -0.1779 \\
\hline LN_OTSUS*(CODE=15) & -0.0084 & -0.0435 \\
\hline LN_OTSUS*(CODE=16) & -0.0046 & -0.0940 \\
\hline LN_OTSUS*(CODE=17) & 0.0008 & 0.0103 \\
\hline LN_OTSUS*(CODE=18) & -0.0110 & -0.0794 \\
\hline LN_OTSUS*(CODE=19) & -0.0818 & -0.6009 \\
\hline LN_OTSUS*(CODE=20) & -0.0115 & -0.2132 \\
\hline LN_OTSUS*(CODE=21) & -0.9236 & $-3.0949 * * *$ \\
\hline LN_OTSUS*(CODE=22) & -0.0117 & -0.0574 \\
\hline LN_OTSUS*(CODE=23) & 0.0352 & 0.8189 \\
\hline KEMISKINAN*(CODE=1) & 0.9834 & 0.1052 \\
\hline KEMISKINAN*(CODE=2) & -2.8889 & -0.7370 \\
\hline KEMISKINAN*(CODE=3) & -0.3368 & -0.0394 \\
\hline KEMISKINAN*(CODE=4) & -0.1391 & -0.0141 \\
\hline KEMISKINAN*(CODE=5) & 10.5517 & 1.1718 \\
\hline KEMISKINAN*(CODE=6) & 1.3168 & 0.3347 \\
\hline KEMISKINAN*(CODE=7) & 2.9871 & 0.2706 \\
\hline KEMISKINAN*(CODE=8) & 1.5635 & 0.3063 \\
\hline KEMISKINAN*(CODE=9) & -58.2414 & $-4.7911 * * *$ \\
\hline KEMISKINAN $*(C O D E=10)$ & -0.0998 & -0.0207 \\
\hline KEMISKINAN*(CODE=11) & 1.8991 & 0.3943 \\
\hline KEMISKINAN*(CODE=12) & 1.3323 & 0.2420 \\
\hline KEMISKINAN*(CODE=13) & -0.0958 & -0.0181 \\
\hline KEMISKINAN*(CODE=14) & -1.9186 & -0.0587 \\
\hline KEMISKINAN*(CODE=15) & 0.3885 & 0.0216 \\
\hline KEMISKINAN*(CODE $=16)$ & 0.6755 & 0.0902 \\
\hline KEMISKINAN*(CODE=17) & 1.0427 & 0.1995 \\
\hline KEMISKINAN*(CODE $=18)$ & 0.1773 & 0.0252 \\
\hline KEMISKINAN*(CODE=19) & 29.2356 & 1.2382 \\
\hline KEMISKINAN*(CODE=20) & 0.6321 & 0.1280 \\
\hline KEMISKINAN*(CODE=21) & -35.1335 & $-2.3119 * *$ \\
\hline KEMISKINAN*(CODE=22) & -0.0059 & -0.0004 \\
\hline KEMISKINAN*(CODE=23) & -3.2232 & -0.4894 \\
\hline R-squared & & 0.9401 \\
\hline Adjusted R-squared & & 0.6580 \\
\hline F-statistic & & $3.3336 * * *$ \\
\hline Durbin-Watson stat & & 2.3619 \\
\hline
\end{tabular}

Sumber

Data Diolah, 2020

Keterangan : $\quad * * *, * * *$ signifikan pada level 1\%, 5\% dan 10\%. Code 1 untuk Simeulu. Code 2 untuk Aceh Singkil. Code 3 untuk Aceh Selatan. Code 4 untuk Aceh Tenggara. Code 5 untuk Aceh Timur. Code 6 untuk Aceh Tengah. Code 7 untuk Aceh Barat. Code 8 untuk Aceh Besar. Code 9 untuk Pidie. Code 10 untuk Bireuen. Code 11 untuk Aceh Utara. Code 12 untuk Aceh Barat Daya. Code 13 untuk Gayo Lues. Code 14 untuk Aceh Tamiang. Code 15 untuk Nagan Raya. Code 16 untuk Aceh Jaya. Code 17 untuk Bener Meriah. Code 18 untuk Pidie Jaya. Code 19 untuk Banda Aceh. Code 20 untuk Sabang. Code 21 untuk Langsa. Code 22 untuk Lhokseumawe. Code 23 untuk Subussalam. 
Berdasarkan Tabel 6 di atas, terlihat bahwa PAD memberikan pengaruh negatif dan signifikan terhadap RKKD pada Kabupaten Aceh Singkil dan Kabupaten Pidie. Ini menunjukkan bahwa di kedua kabupaten tersebut, PAD malah menjadi faktor yang dapat menurunkan tingkat kemandirian daerah. Selain itu, PAD memberikan pengaruh positif dan signifikan terhadap RKKD pada Kabupaten Aceh Utara dan Kota Banda Aceh. Ini menunjukkan bahwa di Aceh Utara dan Banda Aceh, kenaikan PAD akan mendorong daerah tersebut menjadi semakin mandiri.

Untuk dana perimbangan (DP), kajian common effect model per wilayah membuktikan bahwa untuk setiap kabuapaten/kota di Provinsi Aceh, dana perimbangan tidak berpengaruh signfikan terhadap RKKD. Hal ini tentunya berbeda jika dibandingkan dengan pengujian overall yang membuktikan bahwa DP berpengaruh negatif dan signfikan terhadap RKKD. Selanjutnya, OTSUS memberikan pengaruh positif dan signifikan terhadap RKKD pada Kabupaten Pidie, sedangkan OTSUS memberikan pengaruh negatif dan signifikan terhadap RKKD di Kota Langsa. Adapun kemiskinan berpengaruh negatif dan signfikan pada Kabupaten Pidie dan Kota Langsa.

\section{Wald Test Estimation}

Untuk melihat perbedaan pengaruh yang diberikan oleh PAD, DP, OTSUS dan Kemiskinan terhadap RKKD secara statistik, maka dapat dilakukan dengan Uji Wald. Adapun hasil Uji Wald yang telah dilakukan dapat dilihat pada Lampiran 8. Rekapitulasi hasil Uji Wald dalam penelitian ini disajikan pada Tabel 7 berikut:

Sumber

$$
\text { Data Diolah, } 2020
$$

Tabel 7

Wald Test

\begin{tabular}{|c|c|c|}
\hline Perbedaan Pengaruh & $\begin{array}{c}\text { Null } \\
\text { Hypothesis }\end{array}$ & Chi Square \\
\hline PAD dengan $\mathrm{DP}$ & $\begin{array}{l}\mathrm{C}(2)=0, \\
\mathrm{C}(3)=0\end{array}$ & $57.6492 * * *$ \\
\hline PAD dengan OTSUS & $\begin{array}{l}C(2)=0, \\
C(4)=0\end{array}$ & $55.0005 * * *$ \\
\hline $\begin{array}{ll}\text { PAD } & \text { dengan } \\
\text { KEMISKINAN } & \end{array}$ & $\begin{array}{l}C(2)=0, \\
C(5)=0\end{array}$ & $72.4755^{* * *}$ \\
\hline DP dengan OTSUS & $\begin{array}{l}\mathrm{C}(3)=0, \\
\mathrm{C}(4)=0\end{array}$ & $21.0627 * * *$ \\
\hline $\begin{array}{ll}\text { DP } & \text { dengan } \\
\text { KEMISKINAN } & \end{array}$ & $\begin{array}{l}\mathrm{C}(3)=0, \\
\mathrm{C}(5)=0\end{array}$ & $10.4488 * * *$ \\
\hline $\begin{array}{ll}\text { OTSUS } & \text { dengan } \\
\text { KEMISKINAN } & \end{array}$ & $\begin{array}{l}C(4)=0, \\
C(5)=0\end{array}$ & 4.6814* \\
\hline
\end{tabular}

Keterangan : $\quad * * *, * * *$, signifikan pada level 1\%, 5\% dan $10 \%$.

Berdasarkan Tabel 7 di atas, terlihat bahwa terdapat perbedaan pengaruh antara PAD dengan DP terhadap RKKD yang dapat dilihat dari nilai chi square sebesar 57.6492 yang tergolong signifikan pada level 1\%. Ini menunjukkan bahwa secara statistik, pengaruh PAD terhadap RKKD berbeda dengan pengaruh DP terhadap RKKD pada Kabupaten/Kota di Provinsi Aceh. Hal yang sama juga terjadi pada PAD dan OTSUS, dimana pengaruh PAD terhadap RKKD berbeda dengan pengaruh OTSUS terhadap RKKD. Hal tersebut dibuktikan dengan nilai Chi Square sebesar 55.0005 dan signifikan pada level $1 \%$.

Selanjutnya, pengaruh PAD terhadap RKKD dengan pengaruh Kemiskinan terhadap RKKD juga berbeda secara statistik dengan nilai chi square sebesar 72.4755 dan signifikan di level $1 \%$. Hal yang sama juga terjadi pada pengaruh DP terhadap RKKD dengan pengaruh OTSUS terhadap RKKD yang berbeda secara signifikan dengan nilai chi square sebesar 21.0627 dan signifikan pada level $1 \%$. Perbedaan yang signifikan juga terjadi pada pengaruh DP terhadap RKKD dengan pengaruh kemiskinan terhadap RKKD dengan nilai chi square sebesar 10.4488 dan signifikan pada level $1 \%$. 
Adapun pengaruh OTSUS terhadap RKKD juga berbeda dengan pengaruh kemiskinan terhadap RKKD dengan nilai chi square sebesar 4.6814 dan signifikan pada level $10 \%$.

\section{Pembahasan \\ Pengaruh PAD terhadap Rasio Kemandirian Keuangan Daerah}

Hasil penelitian ini membuktikan bahwa PAD berpengaruh positif dan signifikan terhadap rasio kemandirian keuangan daerah pada Kabupaten/Kota di Provinsi Aceh. Artinya, semakin tinggi PAD maka semakin baik tingkat kemandirian keuangan suatu daerah. Hal ini juga membuktikan bahwa PAD menjadi prediktor yang dapat meningkatkan rasio kemandirian keuangan daerah. Dengan kata lain, $\mathrm{H}_{1}$ dalam penelitian ini diterima. Hasil ini juga sejalan dengan beberapa studi sebelumnya yang menemukan bahwa PAD berpengaruh positif terhadap rasio kemandirian keuangan daerah (Heryanti et al., 2019; Purnama, 2016; Anjani et al., 2016; Budi \& Alexander, 2016; Kustianingsih et al., 2018; Sanga et al., 2018).

Pendapatan asli daerah yang merupakan pendapatan daerah yang dapat mencerminkan kondisi riil daerah dan menunjukkan kemandirian keuangan daerah (Nufus \& Asmara, 2017). PAD sendiri dapat diartikan sebagai semua penerimaan daerah yang berasal dari sumber ekonomi asli daerah (Halim, 2007). PAD bersumber dari pajak daerah, retribusi daerah, laba BUMD serta pendapatan asli daerah lain-lain yang sah. PAD yang tinggi menunjukkan bahwa daerah tersebut mampu mendanai kebutuhannya dengan dana yang berasal dari daerah sendiri (bukan bantuan dari pusat), sehingga memberikan dampak pada kemandirian daerah (Andriani \& Wahid, 2018).

Daerah yang memiliki PAD yang tinggi tentunya daerah yang mandiri dan mampu memanfaatkan potensinya untuk menambah kas daerah (Andriani \& Wahid, 2019). Dalam hal tersebut, dibutuhkan pengeluaran-pengeluaran untuk mengembangkan potensi-potensi daerah tersebut, sehingga anggaran belanaja daerah tentunya meningkat, dimana belanja dapat dikucurkan pada aspek penigkatan infrastruktur dalam kaitannya dengan PAD. Lestari et al. (2016) berpendapat bahwa PAD yang tinggi menyebabkan daerah tersebut menjadi mandiri secara keuangannya karena daerah tersebut mampu mendanai pembelanjaan daerahnya dari pendapatan asli daerah. Uraian tersebut menunjukkan bahwa PAD memberikan dampak positif terhadap kemandirian daerah.

PAD menjadi faktor yang dapat meningkatkan kemandirian keuangan daerah (Anjani et al., 2016). Pengelolaan PAD yang baik akan membuat daerah tersebut menjadi lebih mendiri dan tidak tergantung pada dana yang berasal dari pusat. PAD dapat dioptimalkan dengan melakukan pemungutan pajak daerah yang tepat dan tersistem dengan baik, melakukan pemungutan retribusi daerah dan pengawasan yang tepat pada aspek tersebut, karena selama ini masih sering terjadi kebocoran-kebocoran di distribusi daerah, seperti pemungutan parkir liar yang membuat daerah tersebut tidak memperoleh PAD yang optimal. Hal ini harus menjadi perhatian bagi pihak pemerintah daerah dalam meningkatkan kemandirian daerah.

Selanjutnya, agar daerah tersebut mandiri, pembentukan dan pengembangan BUMD juga harus dilakukan, karena selama ini daerah-daerah di Aceh hanya bergantung pada Bank Aceh Syariah sebagai BUMDnya. Dengan adanya dana yang diberikan dari pusat, seharusnya pihak pemerintah daerah dapat mengembangkannya dengan mendirikan BUMD, agar nantinya dapat menghasilkan keuntungan bagi daerah tersebut. Dalam mendirikan BUMD baru, pihak pemerintah daerah juga perlu melihat karakteristik dan potensi daerah, seperti daerah pegunungan yang meliputi Aceh Tengah, Bener Meriah dan Gayo Lues. Pemerintah daerah dapat mendirikan BUMD yang berkaitan dengan pariwisata, seperti penginapan, restoran, cafe dan penyedia jasa liburan. Lain halnya daerah-daerah seperti Aceh Singkil, Subulussalam dan Simeulue yang kaya akan hasil lautnya. Pemerintah dapat mendirikan BUMD yang berkaitan dengan pengelolaan hasil laut, seperti perusahaan ekspor impor lopser, kepiting dan ikan-ikan lainnya.

\section{Pengaruh Dana Perimbangan terhadap Rasio Kemandirian Keuangan Daerah}

Hasil penelitian ini menunjukkan bahwa dana perimbangan berpengaruh negatif dan signifikan terhadap rasio kemandirian keuangan daerah pada kabupaten/Kota di Provinsi Aceh. Ini memberikan indikasi bahwa semakin tinggi dana perimbangan pada suatu daerah, maka tingkat kemandirian keuangan daerah tersebut semakin rendah. Dengan kata lain, $\mathrm{H}_{2}$ dalam penelitian ini diterima. Hasil penelitian ini juga menunjukkan bahwa dana perimbangan menjadi prediktor yang dapat menurunkan tingkat kemandirian keuangan daerah. Beberapa riset-riset sebelumnya juga telah 
membuktikan bahwa dana perimbangan berpengaruh negatif dan signifikan terhadap rasio kemandirian keuangan daerah (Heryanti et al., 2019; Purnama, 2016; Budianto \& Alexander, 2016).

Dana perimbangan terdiri dari 3 komponen, yaitu Dana Alokasi Umum (DAU), Dana Alokasi Khusus (DAK) serta Dana Bagi Hasil (DBH). Ketiga komponen tersebut pada dasarnya merupakan dana dari pusat yang diberikan untuk membantu suatu daerah dalam mengatasi celah fiskal. Ketergantungan daerah terhadap ketiga komponen tersebut menunjukkan bahwa daerah tersebut kurang mandiri. Terlebih ketika daerah terlalu banyak melakukan pembelaan dan pengeluaran dengan dana perimbangan, sehingga sering mengabaikan potensi-potensi daerah yang dapat dikembangkan dalam membantu pemasukan daerah.

Akan tetapi, tanpa adanya dana transfer pusat, daerah juga akan kesulitan dalam mengelola keuangannya. Hal ini menunjukkan bahwa daerah tersebut harus mengefisiensi penggunaan dana perimbangan agar memberikan dampak baik terhadap kemandirian daerah. Sebagai contoh penggunaan DAU dalam keuangan daerah. Seharusnya pemerintah dapat menggunakannya tidak hanya pada belanja pegawai saja, tetapi dapat digunakan untuk pembangunan infrastruktur, dan hal tersebut juga harus dalam batas-batas wajar, dalam artian daerah tersebut tidak mementingkan kepentingan pribadinya dalam menggunakan DAU, tetapi untuk kepentingan rakyat.

Selanjutnya, dana perimbangan juga dapat digunakan untuk meningkatkan kesejahteraan masyarakat, agar kemandirian keuangan daerah dapat meningkat. Sebagai contoh dalam penggunaan DAK, pemerintah daerah dapat menggunakannya untuk program-program yang memang memberikan dampak baik pada daerah, bukan program yang hanya mementingkan urusan sekelompok orang. DAK dapat digunakan dalam program pembangunan fasilitas kesehatan, dimana program tersebut masih menjadi program prioritas pusat. Pihak pemerintah Kabupaten/Kota di Provinsi Aceh dapat melihat daerah-daerah mana yang memiliki tingkat kesehatan masyarakat yang tergolong rendah, kemudian dapat melakukan pembangunan fasilitas-fasilitas kesehatan, agar kesejahteraan masyarakat meningkat.

Selanjutnya, DAK yang merupakan komponen dari dana perimbangan juga dapat digunakan dalam meningkatkan kualitas dan infrastruktur di bidang pendidikan, dimana hal tersebut juga menjadi aspek prioritas pusat. Pemerintah daerah dapat mengalokasikan DAK fisik dengan mendirikan/merenovasi gedung-gedung sekolah, memberikan bantuan kepada siswa yang kurang mampu dan meningkatkan kualitas para pendidik. Hal ini akan memberikan dampak baik pada pengembangan SDM di Aceh dan berdampak pada kesejahteraan masyarakat.

Penggunaan dana perimbangan juga dapat dilihat dari pengunaan DBH. DBH yang merupakan dana bagi hasil daerah dengan pusat dapat berasal dari sektor pajak dan SDA. Misalnya dari sektor pajak yang berkaitan dengan pajak penghasilan. Pemerintah dapat menggunakannya untuk aspek-aspek yang dapat menunjuang infrastruktur daerah, seperti jalan, jembatan, dan saluran air. Hal tersebut akan memberikan kesejahteraan dan kemandirian keuangan daerah.

\section{Pengaruh OTSUS terhadap Rasio Kemandirian Keuangan Daerah}

Berdasarkan hasil analisis data yang telah dilakukan, ditemukan bahwa dana otonomi khusus berpengaruh negatif dan signifikan terhadap rasio kemandirian keuangan daerah pada Kabupaten/Kota di Provinsi Aceh. Hasil tersebut menunjukkan bahwa ketika OTSUS tinggi, kemandirian daerah akan menurun. Dengan kata lain, $\mathrm{H}_{3}$ dalam penelitian ini diterima. Hasil penelitian ini juga memberikan implikasi bahwa OTSUS menjadi elemen yang dapat menurunkan rasio kemandirian keuangan daerah. Beberapa riset sebelumnya juga telah membuktikan bahwa OTSUS memberikan pengaruh negatif terhadap rasio kemandirian keuangan daerah (Nufus \& Asmara, 2017; Tamberan \& Djanggo, 2019).

OTSUS menjadi faktor yang dapat menurunkan kemandirian keuangan daerah. Pada dasarnya, OTSUS merupakan dana yang diberikan oleh pemerintah pusat kepada Aceh.. Berdasarkan Pasal 183 ayat 2 UU No 11 Tahun 2006 menyebutkan bahwa dana OTSUS yang diterima Pemerintah Aceh berlaku untuk jangka waktu 20 tahun, dengan rincian untuk tahun pertama sampai tahun ke 10 setara dengan $2 \%$ dari DAU nasional dan untuk tahun keenambelas sampai kedua puluh, besarnya setara dengan 1\% dari DAU nasional. Dana tersebut juga menjadi dana yang digunakan oleh daerahdaerah di Provinsi Aceh untuk melakukan pembangunan daerah dan pengembangan keistimewaan Aceh. 
Ketergantungan Aceh akan dana OTSUS menjadikan daerah-daerah di Aceh menjadi kurang mandiri. Dana OTSUS yang besar membuat daerah menjadi nyaman dengan dana tersebut, sehingga mengabaikan pendapatan yang semestinya dapat diperoleh dari daerah sendiri. Terlebih lagi danadana tersebut digunakan untuk kepentingan-kepentingan yang kurang tepat dengan pembangunan daerah, menyebabkan kemandirian daerah semakin memburuk. Jika Aceh terlalu bergantung pada OTSUS, maka diperkirakan Aceh akan menjadi semakin tidak mandiri dikarenakan OTSUS akan berakhir di tahun 2028. Ini seharusnya menjadi perhatian bagi pemerintah daerah di Provinsi Aceh untuk dapat mengoptimalkan OTSUS sebelum masanya berakhir.

Akan tetapi, tanpa dana OTSUS pun Aceh akan keberatan dalam menjalankan keuangan daerahnya untuk saat ini. Ini menunjukkan bahwa pemerintah Aceh harus mengupayakan hal-hal yang dapat meningkatkan kemampuan kemandirian keuangan daerah dari adanya dana OTSUS yang diberikan oleh pemerintah pusat. Misalnya untuk program pemberdayaan ekonomi rakyat, pemerintah Aceh dapat membantu dan mengembangkan UMKM yang ada di kabupaten/kota di Provinsi Aceh. Pemerintah Aceh dapat memberikan bantuan permodalan kepada para pelaku UMKM di Aceh, dikarenakan sektor UMKM merupakan sektor yang dapat menyerap banyak tenaga kerja. Hal ini akan mendorong Aceh semakin mandiri, dikarenakan berkembangnya UMKM akan memeberikan efek pada PAD.

Aspek OTSUS lainnya yang juga dapat ditingkatkan adalah aspek pendidikan. OTSUS dapat digunakan untuk mengembangkan tingkat pendidikan masyarakat Aceh dari sekolah dasar hingga perguran tinggi dengan cara memberikan bantuan pendidikan maupun beasiswa kepada anak-anak Aceh. Ini akan mendorong pada kesejahteraan masyarakat Aceh. Dana OTSUS juga dapat dianggarkan pada pembangunan gedung-gedung sekolah, perpustakaan dan fasilitas-fasilitas lainnya yang berkaitan dengan pendidikan. Selain itu, agar Aceh tidak terlalu bergantung dengan dana OTSUS, pihak pemerintah juga dapat membangun infrastruktur-infrastruktur yang ada, agar roda perekonomian Aceh bergerak, dan ketika OTSUS berakhir di tahun 2028, Aceh telah memiliki perekonomian yang mapan dan kemandirian keuangan yang baik.

\section{Pengaruh Kemiskinan terhadap Rasio Kemandirian Keuangan Daerah}

Hasil penelitian ini menemukan bahwa kemiskinan tidak berpengaruh signifikan terhadap rasio kemandirian keuangan daerah. Hal ini menunjukkan bahwa rasio kemandirian keuangan daerah tidak bergantung pada tingkat kemiskinan. Dengan kata lain, $\mathrm{H}_{4}$ dalam penelitian ini ditolak. Hasil penelitian ini juga memberikan implikasi bahwa kemiskinan bukanlah prediktor dalam meningkatkan kemandirian daerah. Beberapa riset sebelumnya juga telah membuktikan bahwa kemiskinan tidak berpengaruh signifikan terhadap rasio kemandirian keuangan daerah (Indrawan, 2016; Setyawati, 2018; Aulia, 2018).

Hasil penelitian ini membuktikan bahwa tidak terdapat hubungan yang signifikan antara kemiskinan terhadap rasio kemandirian keuangan daerah. Kemiskinan merupakan ketidakmampuan masyarakat dalam memenuhi kebutuhan pokoknya. Sementara itu, kemandirian daerah merupakan tingkatan bagaimana daerah tersebut menggunakan dana pendapatan asli daerah dalam melakukan belanja dibandingkan dengan dana transfer pusat. Kemiskinan menjadi tidak berpengaruh signifikan terhadap kemandirian daerah dikarenakan pengeluaran-pengeluaran daerah tidak terlalu difokuskan pada pemberantasan kemiskinan secara langsung. Hasil ini juga memberikan indikasi bahwa pengeluaran daerah di Provinsi Aceh masih belum memberantas kemiskinan di Aceh, sehingga kemiskinan tidak berdampak pada peningkatkan kemandirian keuangan daerah.

Kemiskinan tidak menjadi aspek yang mempengaruhi tingkat kemandirian keuangan daerah. Hal ini jelas terlihat, dimana Aceh menjadi daerah termiskin di Pulau Sumatera (Ururan 6 Nasional), dimana Aceh menjadi provinsi yang memiliki dana dari pusat yang cukup berlimpah. Ini menunjukkan bahwa kemiskinan tidak memiliki hubungan dengan kemandirian keuangan di Aceh, artinya dana-dana dari yang diberikan dari pusat ke daerah tidak memberikan dampak yang nyata dalam memberantas kemiskinan di Aceh.

Seperti halnya dana OTSUS yang diberikan oleh pemerintah pusat dengan tujuan paling utama adalah memberantas kemiskinan di Aceh. Akan tetapi, telah 12 tahun dana OTSUS dikucurkan pemerintah pusat hingga saat ini (dari tahun 2008 hingga sekarang/2020), kemiskinan bukannya berkurang tetapi menjadi perinkat pertama di Pulau Sumatera. Ini menunjukkan bahwa kemiskinan bukanlah faktor bagi kemandirian keuangan daerah. Dalam artian, kemiskinan bukanlah indikator 
yang tepat untuk melihat kemandirian keuangan daerah di Aceh. Ini juga menjadi suatu perhatian bagi Pemerintah Aceh, dimana Aceh harus mampu mengetaskan kemiskinan dengan dana-dana yang diberikan oleh pihak pemerintah pusat kepada Aceh.

\section{KESIMPULAN DAN SARAN \\ Kesimpulan}

Berdasarkan hasil penelitain yang telah dilakukan, maka kesimpulan yang dapat diambil dari penelitian ini adalah sebagai berikut:

1. PAD berpengaruh positif dan signifikan terhadap rasio kemandirian keuangan daerah pada Kabupaten/Kota di Provinsi Aceh.

2. Dana perimbangan berpengaruh negatif dan signifikan terhadap rasio kemandirian keuangan daerah pada Kabupaten/Kota di Provinsi Aceh.

3. Dana Otonomi Khusus (OTSUS) berpengaruh negatif dan signifikan terhadap rasio kemandirian keuangan daerah pada Kabupaten/Kota di Provinsi Aceh.

4. Kemiskinan tidak berpengaruh signifikan terhadap rasio kemandirian keuangan daerah pada Kabupaten/Kota di Provinsi Aceh.

\section{Saran} berikut:

Berdasarkan hasil kesimpulan di atas, maka saran yang dapat penulis berikan adalah sebagai

1. PAD berpengaruh positif dan signifikan terhadap rasio kemandirian keuangan daerah, sehingga disarankan kepada pihak pemerintah daerah Kabupaten/Kota di Provinsi Aceh untuk terus meningkatkan PAD, seperti dengan cara melakukan pengawasan yang tepat pada pemungutan pajak dan retribusi daerah dan mendirikan BUMD baru dengan melihat potensi dari daerahdaerah tersebut, seperti BUMD di bidang pariwisata, ekspor impor komoditas pertanian dan hasil laut, dimana hal-hal tersebu merupakan potensi alam yang dimiliki oleh Aceh.

2. Dana perimbangan berpengaruh negatif dan signifikan terhadap rasio kemandirian keuangan daerah, sehingga disarankan kepada pihak pemerintah daerah Kabupaten/Kota di Provinsi Aceh untuk dapat mengefisiensikan penggunaan dana perimbangan agar tidak terlalu bergantung pada dana transfer pusat, yang dapat dilakunan dengan membangun infrastruktur, meningkatkan fasilitas pendidikan dan kesehatan, dimana hal-hal tersebut dapat memberikan efek baik pada kemandirian keuangan Aceh.

3. Dana Otonomi Khusus (OTSUS) berpengaruh negatif dan signifikan terhadap rasio kemandirian keuangan daerah, sehingga disarankan kepada pemerintah Kabupaten/Kota di Provinsi Aceh untuk bisa mengoptimalkan OTSUS yang dapat dilakukan dengan cara memberdayakan UMKM yang ada di Aceh, dengan membantu permodalan dan pelatihan agar dapat memberikan dampak baik pada perekonomian rakyat Aceh, dan juga meningkatkan tingkat pendikakan di Aceh dengan memberikan bantuan-bantuan dan beasiswa pendidikan, membanguna dan merenovasi sekolah serta meningkatkan kemampuan para pendidik.

4. Kemiskinan tidak berpengaruh signifikan terhadap rasio kemandirian keuangan daerah, sehingga disarankan kepada peneliti lainnya untuk menganalisis faktor-faktor lain yang mempengaruh rasio kemandirian keuangan daerah demi perkembangan di bidang keuangan daerah.

\section{DAFTAR REFERENSI}

Andriani, R. N. R., \& Wahid, N. N. (2019). Pengaruh Pendapatan Asli Daerah dan Dana Perimbangan Terhadap Kemandirian Keuangan Daerah (Studi Kasus pada Pemerintah Kota Tasikmalaya Tahun 2006-2015). Jurnal Akuntansi, 13(1), 30-39.

Anjani, E. S. D., Akram, A., \& Handajani, L. (2016). Hubungan PAD, Belanja Modal dan kinerja Keuangan Pemerintah Daerah di Nusa Tenggara Barat. InFestasi, 11(1), 21-40.

Asmara, A., \& Suci, S. C. (2014). Pengaruh Kemandirian Keuangan Daerah Terhadap Tingkat Kemiskinan di Provinsi Banten. Jurnal Manajemen Pembangunan Daerah, 6(1).

Aulia, S. (2018). Pengaruh Tingkat Kemiskinan, Jumlah Penduduk dan Luas Daerah terhadap Kemandirian Daerah pada Kota Bandung. Jurnal Ekonomi dan Bisnis, 3(2) 
Budianto, B., \& Alexander, S. W. (2017). Pengaruh Pad Dan Dana Perimbangan Terhadap Kinerja Keuangan Pemerintah Kabupaten/Kota Di Provinsi Sulawesi Utara. Jurnal EMBA: Jurnal Riset Ekonomi, Manajemen, Bisnis dan Akuntansi, 4(4).

Daod, T. I., \& Abubakar Hamzah, M. N. (2013). Analisis Kontribusi Pendapatan Asli Daerah terhadap Kemandirian Daerah Provinsi Aceh. Jurnal Ilmu Ekonomi: Program Pascasarjana Unsyiah, 1(4).

Darise, Nurlan. (2009). Pengelolaan Keuangan Daerah. Indeks, Jakarta.

Dewi, Ni Wayan Ratna dan I Dewa Gede Dharma Suputra. (2017). Pengaruh Pendapatan Asli Daerah, Dana Alokasi Umum, Dana Alokasi Khusus dan Belanja Modal Terhadap Pertumbuhan Ekonomi. E-Jurnal Akuntansi Universitas Udayana. Vol 18, No 3.

Dewi, P. A. K., \& Sutrisna, I. K. (2015). Pengaruh Kemandirian Keuangan Daerah dan Pertumbuhan Ekonomi Terhadap Indeks Pembangunan Manusia di Provinsi Bali. E-Jurnal Ekonomi Pembangunan Universitas Udayana, 4(1).

Elmi, B. (2002). Keuangan pemerintah daerah otonom di Indonesia. Penerbit Universitas Indonesia, Jakarta.

Ernayani, R. (2017). Pengaruh Pendapatan Asli Daerah, Dana Alokasi Umum, Dana Alokasi Khusus dan Dana Bagi Hasil terhadap Belanja Daerah (Studi Kasus pada 14 Kabupaten/Kota di Provinsi Kalimantan Timur Periode 2009-2013). JSHP: Jurnal Sosial Humaniora dan Pendidikan, 1(1), 43-52.

Fajar, Nugroho, dan Abdul Rohman. (2012). Pengaruh Belanja Modal Terhadap Pertumbuhan Kinerja Keuangan Daerah Dengan Pendapatan Asli Daerah Sebagai Variabel Intervening (Studi Kasus di Propinsi Jawa Tengah). Diponegoro Journal Of Accounting. Vol 1, No 2.

Febiandani, R., \& Suseno, D. A. (2016). Analisis Hubungan Kemandirian Keuangan Daerah dan Ketergantungan Daerah Terhadap Pengangguran dan Kemiskinan. Economics Development Analysis Journal, 5(2), 217-225.

Ferdiansyah, I., Deviyanti, D. R., \& Pattisahusiwa, S. (2018). Pengaruh pendapatan asli daerah, dana alokasi umum, dana alokasi khusus, dan dana perimbangan terhadap belanja daerah. INOVASI, 14(1), 44-52.

Fajri, Ahmad. (2016). Pengaruh belanja modal terhadap pertumbuhan ekonomi provinsi-provinsi di Sumatera. E-Jurnal Perspektif Ekonomi dan Pembangunan Daerah. Vol. 5, No. 1.

Erawati, N. T., \& Suzan, L. (2015). Pengaruh Pendapatan Asli Daerah Terhadap Tingkat Kemandirian Keuangan Daerah Kota Bandung (Studi Kasus Pada DPKAD Kota Bandung Periode 20092013). eProceedings of Management, 2(3).

Gujarati, Domador N dan Dawn C Porter. (2012). Dasar-Dasar Ekonometrika. Salemba Empat, Jakarta.

Halim, Abdul. (2007). Akuntansi Sektor Publik Akuntansi Keuangan Daerah. Salemba Empat, Jakarta.

Halim, A \& Mujib. (2009). Problem Desentralisasi dan Perimbangan Keuangan Pemerintahan Pusat dan Daerah. UGM, Yogyakarta.

Haviz, Teuku. (2016). Pengaruh Pendapatan Asli Daerah, Dana Perimbangan, Belanja Modal dan Kemiskinan Terhadap Pertumbuhan Ekonomi di Provinsi Aceh. Tesis Program Pascasarjana Ilmu Manajemen, Fakultas Ekonomi dan Bisnis, Universitas Malikussaleh. Tidak Dipublikasikan

Heryanti, C. D., Wahidahwati, W., \& Suryono, B. (2019). Pengaruh Pendapatan Asli Daerah, Dana Perimbangan dan Pertumbuhan Ekonomi Terhadap Kinerja Keuangan Pemerintah Kabupaten/Kota di Provinsi Jawa Timur. Jurnal Analisa Akuntansi dan Perpajakan, 3(1).

Ilyas, M., dan Syafri, A. (2016) Pengaruh Kemiskinan, Pertumbuhan Ekonomi dan IPM terhadap tingkat kemandirian keuangan daerah pada Kabupaten/Kota di Provinsi Jawa Tengah. Jurnal Akuntansi Sektor Publik. 2(1).

Indrajaya, I. G. B., \& Sari, R. P. (2014). Pengaruh Dana Perimbangan dan Pendapatan Asli Daerah terhadap Belanja Daerah Kabupaten Badung. E-Jurnal Ekonomi Pembangunan Universitas Udayana, 3(10). 
Indrawan, M. (2016). Pengaruh Tingkat Kemiskinan dan PAD terhadap Kinerja Kueangan Daerah dengan Model VECM (Studi pada Kabupaten/Kota di Sumatera Selatan). Jurnal Ekonomi dan Bisnis. 1(2).

Indrawan, M. (2017). Pengaruh PAD dan Dana Perimbangan terhadap Rasio Kemandirian Keuangan Daerah dengan PDRB sebagai variabel Moderasi (Studi pada Kabupaten/Kota di Sumatera Selatan). Jurnal EMBA. 2(3).

Indriati, N. (2015). Pengaruh Komponen Pendapatan Asli Daerah terhadap Tingkat Kemandirian Daerah Kabupaten/Kota di Provinsi Aceh. Jurnal Ilmu Ekonomi: Program Pascasarjana Unsyiah, 2(1).

Khairul, Muhammad dan Isnaini Febrianti. (2016). Pengaruh DAU, DAK dan DBH terhadap kemandirian daerah pada Kabupaten/Kota di Provinsi Aceh. Jurnal Organisasi Dan Manajemen.Vol 12. No 1. Hal 65-78.

Kustianingsih, N., Muslimin, M., \& Kahar, A. (2018) Pengaruh Pendapatan Asli Daerah (PAD), Dana Alokasi Umum (DAU), Dana Alokasi Khusus (DAK) Terhadap Tingkat Kemandirian Daerah Pada Pemerintah Daerah Kabupaten Kota Di Provinsi Sulawesi Tengah. Katalogis, 6(6).

Lestari, A., Dali, N., \& Abdullah, M. (2017). Pengaruh dana alokasi umum (DAU) dan Pendapatan asli daerah (PAD) terhadap Belanja modal dan kemandirian keuangan Daerah provinsi sulawesi tenggara. Jurnal Progres Ekonomi Pembangunan (JPEP), 1(2), 44-55.

Mamesah, D. J. (2017). Sistem Administrasi Keuangan Daerah. Gramedia Pustaka Utama, Jakarta.

Manik, T. (2015). Analisis Faktor-faktor yang Mempengaruhi Anggaran Belanja Daerah terhadap Kinerja Keuangan Daerah Kota dan Kabupaten di Provinsi Kepulauan Riau. Jurna Ekonomi Maritim Indonesia (JEMI), 6(2).

Mardiasmo. (2011). Akuntansi Sektor Publik. Andi, Yogyakarta.

Nailufar, F., \& Sufitrayati, S. (2019). Pengaruh Pendapatan Asli Daerah dan Dana Alokasi Khusus terhadap Belanja Daerah di Kota Banda Aceh. Jurnal Samudra Ekonomi dan Bisnis, 10(1).

Nufus, H \& Asmara, J. A. (2017). Pengaruh Pendapatan Asli Daerah dan Dana Perimbangan terhadap Belanja Modal dengan Dana Otonomi Khusus sebagai Pemoderasi pada Kab/kota di Provinsi Aceh. Jurnal Ilmiah Mahasiswa Ekonomi Akuntansi Unsyiah, 2(3), 1-9.

Nurhasanan \& Maria. (2017). Faktor-Faktor Yang Mempengaruhi Tingkat Kemandirian Keuangan Daerah Pada Pemerintahan Kabupaten Dan Kota Di Provinsi Bengkulu Tahun 2010-2013. Jurnal Riset Terapan Akuntansi, 1(1).

Nurhayati, Mafizatun. (2015). Pengaruh Kemandirian Daerah, Investasi Pemerintah, Angkatan Kerja dan Pendapatan Perkapita Terhadap Pertumbuhan Ekonomi Daerah di 33 Profinsi Tahun 2008 - 2013. Jurnal Ilmiah Manajemen dan Bisnis. Volume 1, Nomor 3.

Purnama, W. A. (2016). Pengaruh Komponen PAD, Leverage, dan Dana Perimbangan Terhadap Kemandirian Keuangan Pemerintah Daerah (Studi pada Kabupaten/Kota. di Provinsi Lampung). Jurnal EMBA: Jurnal Riset Ekonomi, Manajemen, Bisnis dan Akuntansi. 2(1).

Putra, I. B. D., \& Dwirandra, A. A. N. B. (2015). Dana alokasi umum, dana bagi hasil, dana alokasi khusus dan pendapatan asli daerah Provinsi Bali. E-Jurnal Akuntansi, 811-827.

Putri, Phany Ineke. (2014). Pengaruh Investasi, Tenaga Kerja, Belanja Modal, dan Infrastruktur Terhadap Pertumbuhan Ekonomi Pulau Jawa. Journal of Economics and Policy. Vol 7, No 2.

Sanga, K. P., Hermanto, S. B., \& Handayani, N. (2018). Pengaruh Penerimaan Daerah Terhadap Kemandirian Keuangan Daerah dengan Belanja Modal Sebagai Variabel Intervening. Jurnal Ekonomi dan Ilmu Sosial. 2(2).

Septiani, I., (2015). Pengaruh PAD, Dana Perimbangan dan Silpa terhadap Kinerja Keuangan Pemerintah Daerah Kabupaten/Kota di Jawa Tengah. Jurnal Ekonomi dan Akuntansi. 2(1).

Sarwono, J. (2016). Prosedur-Prosedur Analisis Popules Aplikasi Riset Skripsi dan Tesis dengan Eviews. Gava Media, Yogyakarta.

Sefty, W., \& Anas., I. (2018). Pengaruh Dana Perimbangan, Risiko Politik dan Pertumbuhan Ekonomi terhadap Rasio Kemandirian Daerah Kota Bandung. Jurnal EMBA. 2(1). 
Seyawati. (2018). Dampak Kemiskinan terhadap Rasio Kemandirian, Pertumbuhan Ekonomi serta Belanja Modal pada Kabupaten/Kota di Sulawesi Selatan. Jurnal Ekonomi, Akuntansi dan Bisnis. 2(1).

Sholihin. (2012). Pengaruh Tingkat Kemiskinan dan PDRB terhadap rasio kemandirian keuangan daerah pada Kabupaten/Kota di Provinsi Sumatera Selatan. Jurnal Ekonomi dan Bisnis. 2(1)

Suparmoko, M. (2011). Keuangan Negara: Dalam Teori dan Praktik Edisi Keenam. Yogyakarta: BPFE-Yogyakarta.

Sugiyono. (2016). Metode Penelitian Kuantitatif, Kualitatif dan R\&D. Bandung: Alfabeta.

Sugiyanta. (2016). Analisis Belanja Modal dan Faktor-Faktor yang Mempengaruhinya Pada Pemerintah Kabupaten/Kota di Indonesia. Jurnal Akuntansi Universitas Jember. Vol. 14, No. 1 .

Suwandi. (2015). Desentralisasi Fiskal dan Dampaknya terhadap Pertumbuhan Ekonomi, Penyerapan Tenaga Kerja, Kemiskinan, dan Kesejahteraan di Kabupaten/Kota Induk Provinsi Papua. Yogyakarta: CV Budi Utama.

Swandewi, Anak Agung Istri Agung. (2014). Pengaruh Dana Perimbangan dan Kemandirian Keuangan Daerah Terhadap Keserasian Anggaran dan Kesejahteraan Masyarakat pada Kabupaten/Kota di Provinsi Bali. Jurnal Ekonomi dan Bisnis. Vol 3, No 7.

Tahar, Afrizal dan Maulida Zakhiya. (2011). Pengaruh Pendapatan Asli Daerah dan Dana Alokasi Umum Terhadap Kemandirian Daerah dan Pertumbuhan Ekonomi Daerah. Jurnal Akuntansi dan Investasi. Vol. 12, No. 1 .

Tamberan, Y. W., \& Djanggo, R. T. P. M. (2019). Analisis Dana Otonomi Khusus dan PDRB Terhadap Kemandirian Daerah di Kabupaten Merauke.Musamus Journal of Economics Development, 1(2), 113-118.

Taryoko. (2016). Analisis Faktor-Faktor yang Mempengaruhi Kemandirian Keuangan Daerah di Daerah Istimewa Yogyakarta Periode 2006-2013. Tesis Fakultas Ekonomi dan Bisnis Universitas Negeri Yogyakarta. Dipublikasikan.

Todaro, Michael P. dan Stephen C. Smith. (2006). Pembangunan Ekonomi (edisi kesembilan, jilid I). Jakarta : Erlangga

Untung, J. (2015). Pengaruh Pendapatan Asli Daerah, Dana Alokasi Umum, Dana Alokasi Khusus, terhadap Belanja Daerah dan Dana Bagi Hasil sebagai Pemoderasi Pemerintah Kabupaten/Kota di Provinsi Jawa Barat Periode Tahun 2010/2014. E-Journal Widya Ekonomika, 1(1).

Widarjono, A. (2013). Ekonometrika. UPP STIM YKPN. Yogyakarta.

Widjaja, HAW. (2002). Otonomi Daerah dan Daerah Otonom. Raja Grafindo Persada. Jakarta. 